\title{
Chemical composition and trophic state of shallow saline steppe lakes in central Asia
}

(North Kazakhstan)

${ }^{*}$ Emil Boros, ${ }^{2}$ Laura Jurecska, ${ }^{3}$ Enikő Tatár, ${ }^{1}$ Lajos Vörös, ${ }^{4,5}$ Marina Kolpakova

${ }^{1}$ Hungarian Academy of Sciences (MTA) Centre for Ecological Research, Balaton Limnological Institute, Klebelsberg Kuno u. 3, H-8237 Tihany, Hungary

${ }^{2}$ Department of Microbiology, Eötvös Loránd University, H-1117 Budapest, Pázmány Péter sétány 1/C, Hungary

${ }^{3}$ Laboratory of Environmental Chemistry and Bioanalytics, Department of Analytical Chemistry, Institute of Chemistry, Eötvös Loránd University, H-1117 Budapest, Pázmány Péter sétány 1/A, Hungary

${ }^{4}$ Sobolev Institute of Geology and Mineralogy, Siberian Branch of Russian Academy of Sciences, 3, Koptyug av., Novosibirsk 630090, Russia

${ }^{5}$ National Research Tomsk Polytechnic University, 30, Lenin av., Tomsk 634050, Russia

*Corresponding author e-mail: boros.emil@okologia.mta.hu; drborose@gmail.com

Phone: +36 87448 244; +36 302861412 


\section{Abstract}

The purpose of this study was to identify the prevailing chemical composition and trophic state of the shallow saline steppe lakes of North Kazakhstan along a wide size range $\left(<1-454 \mathrm{~km}^{2}\right)$ and salinity gradient $\left(2-322 \mathrm{~g} \mathrm{~L}^{-1}\right)$ on a large spatial scale $(1000 \mathrm{~km})$, taking into account the potential effects of human disturbances. Water depth, Secchi disc transparency, temperature, $\mathrm{pH}$, electric conductivity, major ions, total dissolved solids, total organic carbon, total nitrogen and phosphorus, nitrate, soluble reactive phosphorus and chlorophyll $a$ were measured. The equivalent percentage of major ions, Spearman rank correlation, multivariate analyses, equilibrium state of lakes and spatial GIS autocorrelation were calculated. The impact of human disturbances (settlements, farms and mines) on total organic carbon, nitrogen, phosphorus, and chlorophyll $a$ were tested by Kruskal-Wallis ANOVA.

The most common combinations of dominant ions were $\mathrm{Na}-\mathrm{Cl}>\mathrm{SO}_{4}$ and $\mathrm{Na}-\mathrm{Cl}(\mathrm{n}=16 ; 64 \%)$, the $\mathrm{Ca}, \mathrm{Mg}$, $\mathrm{HCO}_{3}$, and $\mathrm{SO}_{4}$ ions precipitate with increasing salinity $\left(2-322 \mathrm{~g} \mathrm{~L}^{-1}\right)$, and ion composition shifts from $\mathrm{Na}>\mathrm{Mg}$ $\mathrm{Cl}>\mathrm{SO}_{4}$, to Na-Cl. The most of the chemical variables positively, but chlorophyll $a$ negatively correlated with total dissolved solids, and the total phosphorus had no significant correlation with any variables. The trophic state of these lakes in most cases exceeded the hypertrophic level. The increase in salinity causes change in chemical composition and effects on the phytoplankton development independently from the size of water surface, and the human disturbances had negligible effect on the trophic state of shallow saline lakes in this region of Kazakhstan.

Key words hypertrophy; large spatial scale; salinity; total organic carbon, human disturbance

\section{Introduction}

The saline lake ecosystems of the world are relatively well known (Hammer 1986) and are important natural assets with considerable aesthetic, cultural, economic, recreational, scientific, conservation, and ecological values (Williams 2002). In central Asia, large saline lakes such as the Caspian Sea, the Aral Sea, Lake Balkhash, Lake Alakol, Lake Tengiz, and Lake Chany were intensively studied in the former USSR (Aladin and Plotnikov 1993). 
Many human activities threaten or have already impacted salt lakes, especially surface inflow diversions and other catchment activities, mining, pollution, biological disturbances (e.g., introduction of exotic species), and climate change, which effects cause loss of biodiversity and fundamental limnological changes (Williams 2002). The crisis of the Aral Sea is one of most spectacular examples of environmental problems in the region, with serious ecological and human consequences (Micklin 2007). In the Aral Sea, the salinity increase was combined with the chemical changes of the water because the relative contribution of $\mathrm{Ca}$ and $\mathrm{SO}_{4}$ ions has decreased (Zavialov et al. 2009).

Meteorological data series show a steady increase in annual and winter temperatures in central Asia since the beginning of the $20^{\text {th }}$ century that might have a strong potential impact on the region's natural ecosystems, agricultural crops, and human health (Lioubimtsevaa et al. 2005; Ibatullin et al. 2009). Since the end of the nineteenth century, when regular hydrological observations began on Lake Chany (Russia, Novosibirsk region) in the northern part of the Central Asian steppe, a constant decrease in the water level has occurred, which correlates with a decrease in regional humidity (Aladin and Plotnikov 1993). Additional problems related to drought stress are low soil organic carbon concentration (SOC), low aggregation, susceptibility to compaction, salinization, and accelerated soil erosion in dry regions. The attendant soil degradation and desertification lead to depletion of SOC, a decline in biomass production, eutrophication/pollution of waters and emission of greenhouse gases (Lal 2004). Aside from soil degradation in organic matter, very few data are available on the organic carbon, inorganic nutrient content, and trophic state of the surface waters in the region.

The steppe region of central Kazakhstan is rich in shallow lakes, with more than 14 thousand such lakes in this area (Urivaev 1959). The estimated total area of standing surface water bodies- including the permanent and intermittent wetlands- in Kazakhstan is approximately $1008800 \mathrm{~km}^{2}$, comprising $37 \%$ of the total area of the country. The saline water bodies are one of the most important aquatic habitats on the steppe in Kazakhstan (Boros et al. 2015). The steppe lakes are not only an important part of the hydrological system but also an important habitat for fish and waterbirds (Bragina and Bragin 2002). The birds in high abundance can have a significant impact on water quality and productivity, if the surface related water volume is relatively small (Boros et al. 2008; Boros et al. 2016). However we were not able to find relationships between waterbirds and trophic states of saline lakes in North Kazakhstan, where the water surface is relatively high comparing with the bird population size (Boros et al. 2015). 
The chemical compositions of saline lakes were intensively studied during 1950s-1970s in the region, when most of larger lakes had Na, Cl, $\mathrm{SO}_{4}$ ion dominance (Esenov and Shlygin 1972; Frolov 1966; Pal'gov et al. 1965; Urivaev 1959), however, very few information has been published about the chemical composition and much less about the trophic state in this century (Bragina and Bragin 2002; Rachikovskaya et al. 2009; Romanova 2008a, 2008b). Fluctuations in the water levels of saline waters cause obvious changes in chemical concentrations and might reflect regional climatic shifts (Williams 1998). The consequences of climate change in the central Asian region (Lioubimtsevaa et al. 2005) may cause a predictable salinity increase in inland waters; however, in contrast with soil researches (Lal 2004), there are much less data on salinization and chemical changes of the saline lakes in the region.

The main purpose of this study was to identify the prevailing chemical composition and trophic state of the shallow saline steppe lakes of central Asia (North Kazakhstan) along a wide lake size range $\left(<1-454 \mathrm{~km}^{2}\right)$ and salinity gradient $\left(2-322 \mathrm{~g} \mathrm{~L}^{-1}\right)$ on a large spatial scale $(1000 \mathrm{~km})$, taking into account the potential effects of human disturbances.

Our first hypothesis was the increase in salinity caused changes in chemical composition and trophic states independently from size of water surface. The second hypothesis was the human disturbances had negligible effect on the trophic state in this region of Kazakhstan.

\section{Methods}

Study area

The study area lies along a $1000-\mathrm{km}$ east-west line in the geographical region of $50^{\circ} \mathrm{N}, 60^{\circ} \mathrm{E}$ and $50^{\circ} \mathrm{N}, 80^{\circ} \mathrm{E}$ in the steppe zone of North Kazakhstan (Fig 1). The territory combines three geological areas: Turan and Western Siberian (North-Kazakhstan) platforms, and Central-Kazakhstan plate (Veselov and Sydykov 2004). Their hydrogeological conditions are very diverse due to the peculiarities of physical and geographical features and geological structure of the area. Within the area, primarily fractures and fracture-karst water are distributed, confined to the pre-Paleozoic - Paleozoic age rocks. Porous and interstitial water of Meso-Cenozoic sediments are also widespread. A clearly defined hydrochemical zonation indicates that the study area has fresh and slightly 
brackish $\mathrm{HCO}_{3}>\mathrm{Cl}-\mathrm{Na}>\mathrm{Mg}$ groundwater (TDS up to $3.0 \mathrm{~g} \mathrm{~L}^{-1}$ ) to highly mineralized Cl-Na (Frolov 1966, Veselov and Sydykov 2004).

The Central Kazakhstan territory has a typical arid steppe climate, where the yearly mean air temperature is $2.4^{\circ} \mathrm{C}$, the winter is dry and cold with little amount of snow (mean: $-17^{\circ} \mathrm{C}$, minimum: $-46^{\circ} \mathrm{C}$ in January), while summer is short and hot (mean: $24^{\circ} \mathrm{C}$, maximum: $42^{\circ} \mathrm{C}$ in July). The yearly sum of rainfall is only between 230-280 mm, and more than $60-80 \%$ of water losses are the result of evaporation by frequent strong winds. The water input of lakes consist of discharge from catchment area, precipitation and groundwater. At the same time, the potential evaporation varies from $580-1080 \mathrm{~mm} / \mathrm{yr}$, which is 3-4 times the amount of rainfall (Bragina and Bragin 2002; Ivashenko 2008).

The investigated lakes are found in closed or terminal basin as an internal endorheic drainage system, which is a favourable hydrogeological condition for salt accumulation. Some of them have endorheic local lakebed (primarily small size pans), while several shallow steppe lakes have connection with each other by permanent and seasonal streams system, and some have inflow by rivers within the basin (e.g. Lake Tengiz, Lake Teniz). The shallow lakes have semistatic or intermittent water balance depending on the hydrological regime of the system. The size of the investigated shallow lakes varied over a wide range $\left(<1-454 \mathrm{~km}^{2}\right)$, based on the available geographical, hydrological data (Bragina and Bragin 2002; Rachikovskaya et. al. 2009), and our estimation by Google Earth spatial measurement tool (Table 1).

Although there were an intensive landscape transformation in Central Asia during the USSR regime in XX. Century, however several drainage systems, intensive farmlands and industrial infrastructure are abandoned today. Furthermore livestock also collapsed since 1991 in Kazakhstan, therefore a large proportion of the world's remaining near-natural grassland is situated in Kazakhstan (Kamp et al. 2016). There were selected lakes for this study within this landscape, which are almost completely surrounded by grassland vegetation with low domestic livestock grazing pressure, without any other visible significant human activity within two hundred meters from the shoreline. The thirty-six percent of the investigated lakes are located in Naurzum (No. 12-18), Altyn Dala (No. 19) and Korgalzhyn (No. 20) State Nature Reserves. (Table 1).

Field measurements and water sampling

Water sampling and field measurements took once on twenty-five typical natural or near-natural steppe lakes in the period of April-June of 2014 and 2015 (Table 1, Fig 1), because the level of these waters could significantly 
decrease in July. Lake selecting strategy was to cover different sizes and types of saline lakes along east-west direction on a large scale in the steppe zone. In spite of a single observation per habitat, the large spatial scale (along $1000 \mathrm{~km}$ transect), different hydrological conditions and wide range of sizes $\left(<1-454 \mathrm{~km}^{2}\right)$ of saline waters, which could offer a representative dataset in the region. Water samples were taken from the open water area far away from the shoreline where water depth had already not changed significantly. Three single subsamples were taken by foot with particular care not to disturb the sediment, filling one litre plastic containers where the single subsamples were mixed and water subsequently analysed in the laboratory. The exact position of sampling sites was obtained with a GPS device.

The water depth $(Z)$ was measured during the sampling at each location with a centimetre-scale gauge. The underwater light conditions were measured with a Secchi disc $\left(\mathrm{Z}_{\mathrm{s}}\right)$, except when the lake bottom was visible. The water temperature $(\mathrm{T}), \mathrm{pH}$, and specific electric conductivity (EC) were measured using a WTW MultiLine P4 field instrument.

Laboratory measurements

Concentrations of six major ions $\left(\mathrm{Na}, \mathrm{K}, \mathrm{Ca}, \mathrm{Mg}, \mathrm{Cl}\right.$, and $\left.\mathrm{SO}_{4}\right)$ were determined according to the standard methods (Eaton et al. 2005). An atomic absorption spectrometer (AAS1N ZEISS Germany) was applied for the measurement of calcium (ASTM 3500-Ca B) and magnesium (ASTM 3500-Mg B) concentrations. A flame emission photometer (PFP7 BUCK Scientific USA) was used for the investigation of sodium (ASTM 3500-Na D) and potassium (ASTM 3500-K D). The concentrations of hydrogen carbonate and bicarbonate ions $\left(\mathrm{HCO}_{3}, \mathrm{CO}_{3}\right)$ were calculated from the results of alkalinity titration (ASTM 2320 B) carried out with methyl red/bromcresol and phenolphthalein indicators, respectively. Chloride was measured by argentometric titrimetry (ASTM 4500-Cl-B). Sulfate ions (ASTM 4500-SO42--E) were measured by applying a turbidimetric method. The total dissolved solids (TDS) are used as a measure of salinity, and the TDS were calculated using the sums of the measured ion concentrations.

The samples for the total organic carbon (TOC) analyses were acidified (to $\mathrm{pH} 2$ with $\mathrm{HCl}$ ) and bubbled to remove dissolved inorganic carbon and the TOC concentration was measured using an Elementar High TOC analyser (ASTM 5310-B). The total nitrogen (TN) samples were digested by sodium hydroxide and potassium- 
persulfate in an autoclave at $121^{\circ} \mathrm{C}$ and were measured with Shimadzu UV-160A spectrophotometer (Eaton et al. 2005). The nitrate-nitrogen $\left(\mathrm{NO}_{3}-\mathrm{N}\right)$ concentration was measured with ultraviolet spectrophotometric screening method (Eaton et al. 2005).

The total phosphorus (TP) content after potassium-persulfate digestion was measured with a Shimadzu UV160A spectrophotometer from unfiltered water samples (Menzel and Corwin 1965). The concentration of soluble reactive phosphorus (SRP) was determined from filtrates of precombusted GF-5 glass fibre filter (nominal pore size $=0.4 \mu \mathrm{m}$ ) based on the method of Murphy and Riley (1962). For chlorophyll $a$ (CHL) measurements, 50-100 $\mathrm{ml}$ of water (depending on turbidity) was filtered through a GF-5 glass fibre filter in the field and then frozen in test tubes. In the laboratory, the CHL concentration was determined spectrophotometrically after hot methanol extraction (Wetzel and Likens 1991).

\section{Calculation of saturation indexes}

Water-rock interaction is one of the main factors controlling the chemical composition of natural water, including saline lake systems (Hardie and Eugster 1970). The thermodynamic calculation of saturation indexes (SI) was performed at $25^{\circ} \mathrm{C}$ and 1 atm using PHREEQC software (Parkhurst and Appelo 2013) with the PITZER database. To assess the extent of the water-rock interaction from the state of thermodynamic equilibrium, a saturation index (SI) was calculated as:

$$
\mathrm{SI}=\lg \frac{[\mathrm{IAP}]}{\mathrm{Ksp}},
$$

where IAP is the ion activity product and $\mathrm{K}_{\mathrm{sp}}$ is the solubility product constant.

If the $\mathrm{SI}$ is below -0.2 , the solution is undersaturated with respect to the corresponding mineral, if the SI exceeds +0.2 , the water is assumed to be supersaturated with this mineral, and \pm 0.2 indicates equilibrium. 
Data analysis

We used a linear fitting to analyse the relationship between the laboratory measurement of TDS and field measurements of EC and used a non-linear fitting between TDS and the saturation indexes. To show any possible relationship among the parameters from all lakes $(n=25)$, we carried out a principal component analysis (PCA), except for $\mathrm{NO}_{3}-\mathrm{N}$ and SRP, because these data are not available from all lakes $(\mathrm{n}=15)$. For this, we ln transformed all measured variables from all lakes (Table 1), except the originally logarithmic $\mathrm{pH}$ and used a zero mean and unit variance standardization. We tested for relationships among the local environmental parameters with a pairwise Spearman rank correlation. In order to estimate the impact of human disturbance such as settlements, farms and mines, the lakes were divided into two equal size groups $\left(\mathrm{n}_{1}=13, \mathrm{n}_{2}=12\right)$. In the case of first group the source of disturbance existed within five kilometres, while in the second group it was out of five kilometres (Table 1). The groups were compared with indicator variables (TOC, TN, TP and CHL), by Kruskal-Wallis ANOVA test. The fitting, PCA ordination, Spearman correlations and Kruskal-Wallis ANOVA test were performed in OriginPro 9 (OriginLab, Northampton, MA) software with significance levels of $\mathrm{p}<0.05$.

The geographic data analyses were performed based on ln transformed variables with ESRI ArcMap 10.2 GIS software. Measures of spatial autocorrelation (Global Moran's Index) were based on feature locations and attribute values using the Global Moran's I statistic. Given a set of weighted features, the "Hot Spot Analyses" identifies statistically significant hot and cold spots using the Getis-Ord Gi* statistic.

\section{Results}

The lakes were very shallow $\left(Z_{\max }=1\right.$ meter) at the sampling locations, and the $Z_{\mathrm{s}}$ was larger than water depth in 17 lakes (68\%) at the time of sampling; therefore, these lakes do not have accurate $\mathrm{Z}_{\mathrm{s}}$ values in this study. The $\mathrm{pH}$ varied within a moderately alkaline range (7.5-9.5), whereas the TDS varied between $2-322 \mathrm{~g} \mathrm{~L}^{-1}$ and the mean value was $60 \mathrm{~g} \mathrm{~L}^{-1}$. Based on the equivalent percentage of major ions (>e\%), $\mathrm{Na}-\mathrm{Cl}>\mathrm{SO}_{4}$ was the most frequent composition $(\mathrm{n}=11 ; 44 \%)$, and the $\mathrm{Na}-\mathrm{Cl}$ type was the second one $(\mathrm{n}=5 ; 20 \%)$; the $\mathrm{Na}-\mathrm{SO}_{4}>\mathrm{Cl}$ and $\mathrm{Na}>\mathrm{Mg}-\mathrm{Cl}$ types had the same frequency $(n=4-4 ; 16-16 \%)$, whereas the $\mathrm{Na}>\mathrm{Mg}-\mathrm{Cl}>\mathrm{SO}_{4}$ type had a single representative $(\mathrm{n}=1$; $4 \%$ ) among the lakes. Based on the $\mathrm{e} \%$, the major ion order was $\mathrm{Na}>\mathrm{Mg}$, and $\mathrm{Cl}>\mathrm{SO}_{4}$ in the ion pools (Table 1 ; Fig 1; Fig 2a, 2b). 
The relationship between laboratory measurement of TDS and field measurement of EC can be described with a linear equation and significant correlation (2):

$\mathrm{EC}=0.92 \times \mathrm{TDS}$

$\left(\mathrm{N}=25 ; \mathrm{df}=23 ; \mathrm{r}^{2}=0.917 ; \mathrm{p}<0.05\right)$

The thermodynamic calculations of the equilibrium state of lakes with carbonate minerals showed that the majority of them are oversaturated with respect to calcite, dolomite, and magnesite (Fig 3) that results in the removal of significant amounts of $\mathrm{Ca}, \mathrm{Mg}, \mathrm{HCO}_{3}$, and $\mathrm{CO}_{3}$ ions from solution. Moreover, according to the results, lakes with a $\mathrm{SO}_{4}$ concentration of more than $7.5 \mathrm{~g} \mathrm{~L}^{-1}$ and a Ca-concentration of more than $0.3 \mathrm{~g} \mathrm{~L}^{-1}$ are in equilibrium with gypsum and anhydrite. Precipitation of gypsum leads to a decrease in the remaining Ca content in solution, whereas the $\mathrm{Mg}$ content continues to grow steadily. The concentration of $\mathrm{Na}$ in solution is also defined by a secondary mineral phase such as halite, but saturation with it appears only at the latest stage of chemical evolution with TDS of more than $300 \mathrm{~g} \mathrm{~L}^{-1}$. Sequential precipitation of carbonate, sulphate and chloride minerals lead to changes in the chemical composition of water such as the ion type shifting from $\mathrm{Ca}-\mathrm{HCO}_{3}$ to $\mathrm{Na}>\mathrm{Mg}-$ $\mathrm{Cl}>\mathrm{SO}_{4}$, to $\mathrm{Na}-\mathrm{Cl}>\mathrm{SO}_{4}$, and supersaturation of $\mathrm{Na}-\mathrm{Cl}$ (Fig 3).

The TOC concentration varied between 12 and $125 \mathrm{mg} \mathrm{L}^{-1}$, whereas the TN $\left(213-10083 \mu \mathrm{g} \mathrm{L}^{-1}\right)$ and TP concentrations (26-1122 $\mu \mathrm{g} \mathrm{L}^{-1}$ ) showed much larger variation. The chlorophyll a concentration also varied in a wide range, between 5 and $378 \mu \mathrm{g} \mathrm{L}^{-1}$. Both mean TP $\left(283 \mu \mathrm{g} \mathrm{L}^{-1}\right)$ and CHL $\left(38 \mu \mathrm{g} \mathrm{L}^{-1}\right)$ concentration of all lakes exceeded the hypertrophic level (OECD 1982).

The $\mathrm{NO}_{3}-\mathrm{N}$ varied between $15-657 \mu \mathrm{g} \mathrm{L}^{-1}$ concentration range, which represented $0.3-30 \%$ of the TN. The SRP varied between 5-219 $\mu \mathrm{g} \mathrm{L}^{-1}$ concentration range, which formed only 1-19\% phosphorus content of the TP. Due to the high variability of nitrogen and phosphorus concentrations, the N/P ratio also varied in a wide range (1-213) and was above the Redfield-ratio (Redfield 1934) in most lakes (76\%). (Table 1).

Taking into account the significant Spearman pairwise correlations $(\mathrm{p}<0.05)$, most of the variables were positively correlated with TDS, except for $\mathrm{pH}, \mathrm{Ca}, \mathrm{HCO}_{3}+\mathrm{CO}_{3}, \mathrm{TP}, \mathrm{CHL}$, but only the CHL had significant negative correlation with TDS. Whereas most of the ion concentrations were negatively correlated with the Z, except for $\mathrm{HCO}_{3}+\mathrm{CO}_{3}$. The $\mathrm{Na}, \mathrm{K}, \mathrm{Cl}$, and $\mathrm{SO}_{4}$ were positively correlated with most of the ions, except for Ca and $\mathrm{HCO}_{3}+\mathrm{CO}_{3}$. The $\mathrm{Ca}$ concentration had a positive correlation only with $\mathrm{Mg}$, whereas it was negatively correlated with $\mathrm{HCO}_{3}+\mathrm{CO}_{3}$. The $\mathrm{Mg}$ was also correlated with all ion concentrations except for $\mathrm{HCO}_{3}+\mathrm{CO}_{3}$. The TOC was 
closely correlated with $\mathrm{TN}$ and most ion concentrations except for $\mathrm{Ca}$ and $\mathrm{Cl}$ whereas the $\mathrm{TN}$ had a positive correlation only with the $\mathrm{Na}, \mathrm{K}$ and $\mathrm{HCO}_{3}+\mathrm{CO}_{3}$ ions. The CHL had only a significantly negative correlation with $\mathrm{Z}, \mathrm{Na}, \mathrm{Mg}, \mathrm{Cl}$, and TDS. The $\mathrm{pH}$ had only one significant (negative) correlation with the T, and the TP had no considerable correlation with any variables. Based on the PCA ordination (Fig 4), most of the variables (T, Na, K, $\mathrm{Mg}, \mathrm{Cl}, \mathrm{SO}_{4}$, and TDS) were related to the first component (36.51\%) and four variables $\left(\mathrm{Z}, \mathrm{HCO}_{3}+\mathrm{CO}_{3}\right.$, TOC, and $\mathrm{TN})$ were related to the second component $(26.13 \%)$, whereas only Ca and CHL were related to the third component $(15.16 \%)$.

Based on GIS spatial autocorrelation, only the TP had a non-random spatial distribution $(\mathrm{p}<0.05)$ within the investigation area. The spatial "Hot Spot Analyses" showed that the significantly highest values of TP were located in two neighbouring lakes. These lakes had the lowest $\mathrm{Z}_{\mathrm{s}}$ value $(2 \mathrm{~cm})$ in the sampling period (Table 1).

Based on Kruskal-Wallis ANOVA test, there were not any significant differences between the median values (TOC, TN, TP and CHL) of two the lake groups. In the case of first group the source of disturbance existed within five kilometres, while in the second one it was out of five kilometres (Table 2).

\section{Discussion}

According to the previous studies, $\mathrm{Na}, \mathrm{Mg}, \mathrm{Cl}$, and $\mathrm{SO}_{4}$ are the dominant ions (Fig $2 \mathrm{a}, 2 \mathrm{~b}$ ) of the saline steppe lakes in North Kazakhstan (Esenov and Shlygin 1972; Frolov 1966; Pal'gov et al. 1965; Rachikovskaya et al. 2009; Romanova 2008a, 2008b; Urivaev 1959). Aside from the former studies (Aladin and Plotnikov 1993) of most important saline waters in the region (e.g., the Caspian Sea, the Aral Sea, Lake Balkhash, Lake Alakol, Lake Tengiz, and Lake Chany complex), this study covering a wide range of size and salinity on a large spatial scale demonstrate the similarity of medium and small lakes to the chemistry of large lakes. Thus, the most common combinations of dominant ions are $\mathrm{Na}-\mathrm{Cl}>\mathrm{SO}_{4}$ and $\mathrm{Na}-\mathrm{Cl}(\mathrm{n}=16 ; 64 \%)$ in their current state (Fig 1, Fig 2a, 2b). Our results suggest that the ongoing desiccation of the central Asian steppe and the predictable salinity increase can cause more intensive precipitation of carbonate and sulphate minerals, which leads to reduction of $\mathrm{Ca}, \mathrm{Mg}$, $\mathrm{HCO}_{3}$, and $\mathrm{SO}_{4}$ ions in the dissolved solids. As a result, the ion composition of these steppe lakes is shifting from $\mathrm{Ca}-\mathrm{HCO}_{3}$ to $\mathrm{Na}>\mathrm{Mg}-\mathrm{Cl}>\mathrm{SO}_{4}$, to $\mathrm{Na}-\mathrm{Cl}>\mathrm{SO}_{4}$ and then to $\mathrm{Na}-\mathrm{Cl}$ (halite) after reaching an equilibrium state with respect to halite (Fig 3), similar to the chemical change of the Aral Sea (Zavialov et al. 2009). Thus we can confirm 
the hypothesis: the increase in salinity causes changes in chemical composition along the wide salinity gradient in the shallow steppe lakes on a large spatial scale independently from the size of water surface. Earlier this phenomenon was only observed in the case of larger lakes within the region (Zavialov et al. 2009). In addition, we have proven that TDS can be reliably estimated via a simple TDS=EC $\times 1.08$ empirical relationship in a wide range of salinity.

TOC data are scarcely available from lakes in the central Asian region, and the new data from this study proved that most lakes had higher TOC concentrations than is common in eutrophic lakes and marshes (Thurman 1985). Although the TOC may vary over a wide range $\left(<0.1-110 \mathrm{mg} \mathrm{L}^{-1}\right)$ in the athalassic saline inland waters, it is generally higher than $10 \mathrm{mg} \mathrm{L}^{-1}$ in most lakes on a worldwide scale (Hammer 1986), as in the case of our lakes. The relatively high organic carbon concentration of these waters might be also a consequence of water volume decrease.

Whereas the concentrations of most of the inorganic and organic components increase with parallel decreases in the water level, furthermore hypertrophic state is common in shallow saline lakes (Hammer 1986; Williams 1998). Following the general trend in this study, most of the variables positively correlated with TDS and negatively with the water depth. In contrast to most chemical components the CHL had negative correlation with the TDS and the TP had no significant correlation with any other variables. The trophic state of these lakes based on TP and CHL concentration in most cases exceeded the hypertrophic level (OECD 1982), which is common in shallow saline lakes (Hammer 1986; Williams 1998). Therefore we were able to confirm the hypothesis, that an increase in salinity causes change in chemical composition and effects on the phytoplankton development independently from the size of water surface.

The $\mathrm{NO}_{3}-\mathrm{N}$ and SRP concentrations in this study are similar to the former published data from the north steppe region (Bragina and Bragin, 2002; Burlibaeva et al. 2007), but the concentration of nitrogen and phosphorus of deeper lakes (e.g. Lake Balkhas) is an order of magnitude less (Romanova 2008a, 2008b). The SRP formed only $1-19 \%$ of the TP in this study, which reflects the limited availability of this nutrient. Usually, the TP concentration rather depends on turbidity due to sediment resuspension by the characteristically strong wind action on the steppe, what is a common phenomenon in the shallow lakes (Scheffer 1998). Although the TP is the most common trophic state indicator in lakes, it seems in these shallow saline lakes this parameter in many cases overestimate the trophic state, because its minor part is biologically available based on the SRP. 
Although, the distance of human disturbance sources had no detectable effect on the TOC, TN, TP and CHL concentration values, we have to note, there were no large settlements, intensive livestock farming and other infrastructures close to the lakes. Therefore we could confirm the second hypothesis, as the human disturbances had negligible effect on the trophic state in this region of Kazakhstan. This result reflects the benefit of less intensive land use activity in the area compared to former times, which allows a large proportion of the world's remaining near-natural lake systems in Kazakhstan.

This study presents the key abiotic features and trophic state over a wide size range $\left(<1-454 \mathrm{~km}^{2}\right)$ of shallow steppe saline lakes on a large spatial scale $(1000 \mathrm{~km})$. Due to the lack of a significant geographical pattern in the environmental variables on the large spatial scale in the area, the differences in abiotic features and trophic states of these lakes rather depend on the climate, local hydrological regime and moderate land use activity, than intensive human disturbances. Due to the ongoing climate change, a salinity increase is predictable in these saline steppe lakes. We would like to contribute with our results to a better understanding and forecasting of their environmental status as well as to appropriate planning and management.

\section{Acknowledgements}

This project was carried out in the framework of a scientific and technical cooperation agreement between Kiskunság National Park Directorate (Hungary) and Naurzum State Nature Reserves, which was promoted by the Agricultural Ministries of Kazakhstan and Hungary. We would like to thank colleagues at the Naurzum, Korgalzhyn, and Altyn Dala National Reserves; Kazakh National Agrarian University (Kazakhstan); and the Kiskunság National Park Directorate (Hungary) for all of their work and help, and we would like to especially thank Tatyana Bragina and Evgeny Bragin for their scientific assistance. The project was also funded by the Mektep Publishing House (Kazakhstan), Naturglobe Ltd. and LAC Holding (Hungary). We especially thank Kairat Bibekov for essential work as the technical manager in this project. The thermodynamic modelling was financially supported by the Russian Scientific Fund (Project 15-17-10003). 


\section{References}

Aladin, N. V., \& Plotnikov, I. S. (1993). Large saline lakes of former USSR: a summary review. Hydrobiologia $267,1-12$.

Boros, E., Nagy, T., Pigniczki, Cs., Kotymán, L., V.-Balogh, K., \& Vörös, L. (2008). The effect of aquatic birds on the nutrient load and water quality of soda pans in Hungary. Acta Zoologica Academiae Scientiarum Hungaricae 54(Suppl. 1), 207-224.

Boros, E., Pigniczki, Cs., Sápi, T., V.-Balogh, K., Vörös, L., \& Somogyi, B. (2016). Waterbird-mediated Productivity of Two Soda Pans in the Carpathian Basin in Central Europe. Waterbirds 39(4), 388-401.

Boros, E., Vörös, L., Bulibayeva, D., Aldiyarova, A., \& Narbayeva, K. (2015). Salinity and trophic status of the shallow standing water bodies in the Central Asian steppe (North Kazakhstan). in: Water supply and water management in irrigated agriculture and irrigation of pastures (dedicated to the 85th anniversary of the University's foundation and the 100th anniversary of outstanding scientist of water science of Kazakhstan, statesman Tazhibayev L.E.), Almaty, Kazakhstan, (pp. 164-172). Conference book (ISBN 978-601-241-548-1).

Bragina, T. M., \& Bragin, E. A. (eds) (2002). The most important wetlands of Northern Kazakhstan (in the Kostanay and western parts of the North Kazakhstan region). World Wildlife Fund (WWF), Moscow, Russia.

Burlibaeva, M. Zh., Korocskinoi L. Ja., Kaseeva, V. A., Erohova, S. H., \& Ivasenko, A. A. (eds) (2007): Globally significant wetlands of Kazakhstan. Vol. 2. Tengiz-Korgalzhyn lake system. Astana.

Eaton, A. D., Clesceri, L. S., Rice, E. W., Greenberg, A. E., \& Franson, M. A. H. (eds) (2005). Standard methods for the examination of water and wastewater. 21st Edition, American Public Health Association, Washington DC.

Esenov, S. E., \& Shlygin, E. D. (1972). Geology of USSR. V. 20. Central Kazakhstan. Geological specification. Moscow: Nedra.

Frolov, P. M. (ed) (1966). Hydrogeology of USSR. Vol. 33. Northern Kazakhstan. Moscow: Nedra.

Hammer, U. T. (1986). Saline lake ecosystems of the World. Dr W. Junk Publishers, The Hague.

Hardie, L. A., \& Eugster, H. P. (1970). The evolution of closed-basin brines. Mineral. Soc. Am. Spec. Publ. V. 3, 273-290. 
Ibatullin, S., Yasinsky, V., \& Mironenkov A. (2009). The impact of climate change on water resources in Central Asia. Sector report no. 6. Eurasian Development Bank. Kazakhstan, Almaty.

Ivashenko, A. A. (2008). Reserves and National Parks of KAZAKHSTAN. Almatykitap baspasy.

Kamp, J., Koshkin, M. A., Bragina, T. M., \& Katzner, T. E., Milner-Gulland, E. J., Schreiber, D., Sheldon, R., Shmalenko, A., Smelansky, I., Terraube, J., Urazailev, R. (2016). Persistent and novel threats to the biodiversity of Kazakhstan's steppes and semi-deserts. Biodiversity and Conservation 25(12), 2521-2541.

Lal, R. (2004). Carbon sequestration in soils of central Asia. Land Degradation and Development 15(6), 563572.

Lioubimtsevaa, E., Colea, R., Adamsb, J. M., \& Kapustinc, G. (2005). Impacts of climate and land-cover changes in arid lands of Central Asia. Journal of Arid Environments 62, 285-308.

Menzel, D.H., \& Corwin, N. (1965). The measurement of total phosphorus in seawater based on the liberation of organically bound fractions by persulfate oxidation. Limnology and Oceanography 10, 280-282.

Micklin, P. (2007). The Aral Sea Disaster. Annual Review Earth Planetary Sciences 35, 47-72.

Murphy, J., \& Riley, J. P. (1962). A modified single solution method for the determination of phosphate in natural waters. Analytica Chimica Acta 27, 31-36.

OECD [Organization for Economic Cooperation and Development]. (1982). Eutrophication of waters. Monitoring, Assessment and Control. Final Report OECD Cooperative Programme on Monitoring of Inland Waters (Eutrophication Control), Environment Directorate, OECD, Paris.

Pal'gov, N. N., Popov, G. Z., Nurmagambetova, L. S., Sosedov, J. S., \& Chupahin, V. (eds) (1965). Hydrological studies in Kazakhstan. V.11. Alma-Ata: Science.

Parkhurst, D. L., \& Appelo, C. A. J. (2013). Description of Input and Examples for PHREEQC Version 3 A Computer Program for Speciation, Batch-Reaction, One-Dimensional Transport, and Inverse Geochemical Calculations. U.S. Geological Survey, Denver, Colorado.

Rachikovskaya, E. I., Erohov, C. N., Evstrifeev, U. G., Abieva, D. K., \& Omarbekova, A. S. A. (eds) (2009). Atlas of Kazakhstan's wetlands (demonstration on three globally significant wetlands). The atlas was developed by the GEF/Government of the RK/UNDP project. Astana.

Redfield, A. C. (1934). On the proportions of organic derivatives in sea water and their relation to the composition of plankton (pp. 176-192). In: James Johnstone Memorial Volume. (Daniel R. J. ed). University Press of Liverpool.

Romanova, S. M. (2008a). Endorheic water reservoirs of Kazakhstan. Almaty. 
Romanova, S. M. (2008b). Bottomless reservoirs of Kazakhstan. Volume 1: Hydrochemical regime. Ministry of Education and Science of the Republic of Kazakhstan, Kazakh National University, Al-Farabi Kazakh National University, Almaty.

Scheffer, M., (1998). Ecology of Shallow Lakes. Chapman and Hall London.

Thurman, E. M. (1985). Organic geochemistry of natural waters. Dordrecht, Martinus Nijhoff.

Urivaev, V. A. (ed) (1959). Surface water resources in areas of virgin and fallow lands. Leningrad: Hydrometeoizdat.

Veselov, V. V., \& Sydykov, Zh. S. (2004). Hydrogeology of Kazakhstan. Almaty.

Wetzel, R. G., \& Likens, G. E. (1991). Limnological analysis. Springer-Verlag, New York, US.

Williams, W. D. (1998). Guidelines of lake management. Volume 6. Management of Inland Saline Waters. International Lake Environment Committee, United Nations Environment Programme.

Williams, W. D. (2002). Environmental threats to salt lakes and the likely status of inland saline ecosystems in 2025. Environmental Conservation 2, 154-167.

Zavialov, P. O., Ni, A. A., Kudyshkin, T. V., Ishniyazov, D. P., Tomashevskaya, I. G., \& Mukhamedzhanova, D. (2009). Ongoing Changes of Ionic Composition and Dissolved Gases in the Aral Sea. Aquat Geochem $15,263-275$. 
Table 1 Summary of the geographic, hydrologic, human disturbance sources and measured variables of shallow saline lakes in North Kazakhstan ( $\mathrm{n}=25$ )

\begin{tabular}{|c|c|c|c|c|c|c|c|c|c|c|c|c|c|c|c|c|c|c|c|c|c|}
\hline No. & Latitude & Longitude & Lake name & Area & Date & Z & $Z_{s}$ & $\mathrm{~T}$ & $\mathrm{pH}$ & $\mathrm{EC}$ & TDS & Ion type & TOC & $\mathrm{TN}$ & $\mathrm{NO}_{3}-\mathrm{N}$ & $\mathrm{TP}$ & SRP & CHL & Type & Disturbance & Reserve \\
\hline & $\mathrm{N}$ & $\mathrm{E}$ & & $\mathrm{Km}^{2}$ & $\mathrm{~d} / \mathrm{m} / \mathrm{y}$ & $\mathrm{cm}$ & $\mathrm{cm}$ & ${ }^{\circ} \mathrm{C}$ & & $\mathrm{mScm}^{-1}$ & $\mathrm{gL}^{-1}$ & & $\mathrm{mgL}^{-1}$ & $\mu \mathrm{gL}^{-1}$ & $\mu \mathrm{gL}^{-1}$ & $\mu \mathrm{gL}^{-1}$ & $\mu \mathrm{gL}^{-1}$ & $\mu \mathrm{gL}^{-1}$ & & & \\
\hline 1 & $51^{\circ} 19^{\prime} 18.12^{\prime \prime}$ & $62^{\circ} 21^{\prime} 25.78^{\prime \prime}$ & Teniz & $6.4^{(1)}$ & $29 / 04 / 15$ & 70 & 8 & 15 & 8.9 & 10.2 & 6 & $\mathrm{Na}>\mathrm{Mg}-\mathrm{Cl}$ & 56 & 4200 & 39 & 351 & 13 & 378 & Semistatic & Settlement $<1 \mathrm{~km}$ & \\
\hline 2 & $51^{\circ} 20^{\prime} 32.44^{\prime \prime}$ & $62^{\circ} 23^{\prime} 35.96^{\prime \prime}$ & Sukyrkol & $1.4^{(1)}$ & $29 / 04 / 15$ & 60 & 23 & 16 & 9.1 & 6.7 & 4 & $\mathrm{Na}>\mathrm{Mg}-\mathrm{Cl}$ & 51 & 3500 & 300 & 227 & 100 & 169 & Semistatic & Settlement $<1 \mathrm{~km}$ & \\
\hline 3 & $51^{\circ} 12^{\prime} 36.05^{\prime \prime}$ & $62^{\circ} 31^{\prime} 33.45^{\prime \prime}$ & Kaiyndysor & $5.4^{(1)}$ & $30 / 04 / 15$ & 20 & $>20$ & & 8.2 & 137.3 & 131 & $\mathrm{Na}-\mathrm{Cl}>\mathrm{SO}_{4}$ & 48 & 3100 & 87 & 135 & 29 & 23 & Intermittent & $>5 \mathrm{~km}$ & \\
\hline 4 & $51^{\circ} 13^{\prime} 7.39^{\prime \prime}$ & $62^{\circ} 34^{\prime} 57.09^{\prime \prime}$ & Asubastysor & $1-1.5$ & $29 / 04 / 15$ & 20 & $>20$ & 14 & 8.7 & 99.3 & 88 & $\mathrm{Na}-\mathrm{Cl}>\mathrm{SO}_{4}$ & 66 & 5500 & 120 & 100 & 40 & 41 & Semistatic & $>5 \mathrm{~km}$ & \\
\hline 5 & $51^{\circ} 19^{\prime} 45.61^{\prime \prime}$ & $62^{\circ} 40^{\prime 2} 21.14^{\prime \prime}$ & Ukrash & $11.5^{(1)}$ & $30 / 04 / 15$ & 10 & $>10$ & 26 & 7.5 & 237.0 & 322 & $\mathrm{Na}-\mathrm{Cl}$ & 48 & 5500 & 15 & 26 & 5 & 6 & Intermittent & $>5 \mathrm{~km}$ & \\
\hline 6 & $51^{\circ} 22^{\prime} 4.04^{\prime \prime}$ & $62^{\circ} 48^{\prime} 26.11^{\prime \prime}$ & Zharsor & $6^{(1)}$ & $30 / 04 / 15$ & 10 & $>10$ & 24 & 8.5 & 69.8 & 70 & $\mathrm{Na}-\mathrm{Cl}$ & 25 & 1900 & 177 & 109 & 59 & 9 & Intermittent & $>5 \mathrm{~km}$ & \\
\hline 7 & $51^{\circ} 24^{\prime} 38.08^{\prime \prime}$ & $63^{\circ} 1^{\prime} 23.69^{\prime \prime}$ & Unknown & $1.5-2$ & $02 / 05 / 15$ & 20 & $>20$ & 19 & 8.9 & 99.5 & 79 & $\mathrm{Na}-\mathrm{Cl}>\mathrm{SO}_{4}$ & 125 & 9100 & 81 & 187 & 27 & 10 & Intermittent & $>5 \mathrm{~km}$ & \\
\hline 8 & $51^{\circ} 22^{\prime} 12.28^{\prime \prime}$ & $63^{\circ} 1^{\prime} 46.92^{\prime \prime}$ & Unknown & $1-1.5$ & $02 / 05 / 15$ & 70 & 8 & 24 & 8.6 & 22.2 & 14 & $\mathrm{Na}-\mathrm{Cl}>\mathrm{SO}_{4}$ & 43 & 4300 & 72 & 95 & 24 & 8 & Semistatic & $>5 \mathrm{~km}$ & \\
\hline 9 & $51^{\circ} 21^{\prime} 28.11^{\prime \prime}$ & $63^{\circ} 1^{\prime} 25.95^{\prime \prime}$ & Kaindysor & $3-4$ & $02 / 05 / 15$ & 10 & $>10$ & 26 & 8.1 & 159.5 & 149 & $\mathrm{Na}-\mathrm{Cl}>\mathrm{SO}_{4}$ & 74 & 6200 & 300 & 309 & 100 & 10 & Intermittent & $>5 \mathrm{~km}$ & \\
\hline 10 & $51^{\circ} 32^{\prime} 7.15^{\prime \prime}$ & $63^{\circ} 41^{\prime} 0.40^{\prime \prime}$ & Unknown & $<1$ & $04 / 05 / 15$ & 10 & 2 & 20 & 8.5 & 31.3 & 23 & $\mathrm{Na}-\mathrm{SO}_{4}>\mathrm{Cl}$ & 79 & 7700 & 657 & 1102 & 219 & 47 & Intermittent & Settlement $<0.4 \mathrm{~km}$ & \\
\hline 11 & $51^{\circ} 32 ' 2.42^{\prime \prime}$ & $63^{\circ} 41^{\prime} 27.39^{\prime \prime}$ & Unknown & $<1$ & $04 / 05 / 15$ & 20 & 2 & 19 & 8.7 & 21.4 & 16 & $\mathrm{Na}-\mathrm{SO}_{4}>\mathrm{Cl}$ & 63 & 5800 & 273 & 1122 & 91 & 57 & Intermittent & Settlement $<0.2 \mathrm{~km}$ & \\
\hline 12 & $51^{\circ} 21^{\prime} 25.90^{\prime \prime}$ & $64^{\circ} 18^{\prime} 40.73^{\prime \prime}$ & Shoshkakol & $5.1^{(1)}$ & $29 / 05 / 14$ & 25 & 25 & 16 & 8.3 & 7.7 & 6 & $\mathrm{Na}-\mathrm{SO}_{4}>\mathrm{Cl}$ & 38 & 2400 & & 238 & & 34 & Semistatic & $>5 \mathrm{~km}$ & + \\
\hline 13 & $51^{\circ} 27^{\prime} 39.99^{\prime \prime}$ & $64^{\circ} 30^{\prime} 5.79^{\prime \prime}$ & Big Aqsuat & $203^{(1)}$ & $24 / 04 / 15$ & 20 & $>20$ & 10 & 7.9 & 7.7 & 13 & $\mathrm{Na}-\mathrm{Cl}>\mathrm{SO}_{4}$ & 13 & 800 & 237 & 146 & 79 & 12 & Semistatic & Farm $<2 \mathrm{~km}$ & + \\
\hline 14 & $51^{\circ} 30^{\prime} 18.98^{\prime \prime}$ & $64^{\circ} 29^{\prime} 38.37^{\prime \prime}$ & Little Aqsuat & $1.3^{(1)}$ & $29 / 05 / 14$ & 5 & $>5$ & 14 & 8.5 & 12.2 & 9 & $\mathrm{Na}-\mathrm{Cl}>\mathrm{SO}_{4}$ & 25 & 1500 & 123 & 154 & 41 & 26 & Intermittent & Farm $<0.2 \mathrm{~km}$ & + \\
\hline
\end{tabular}




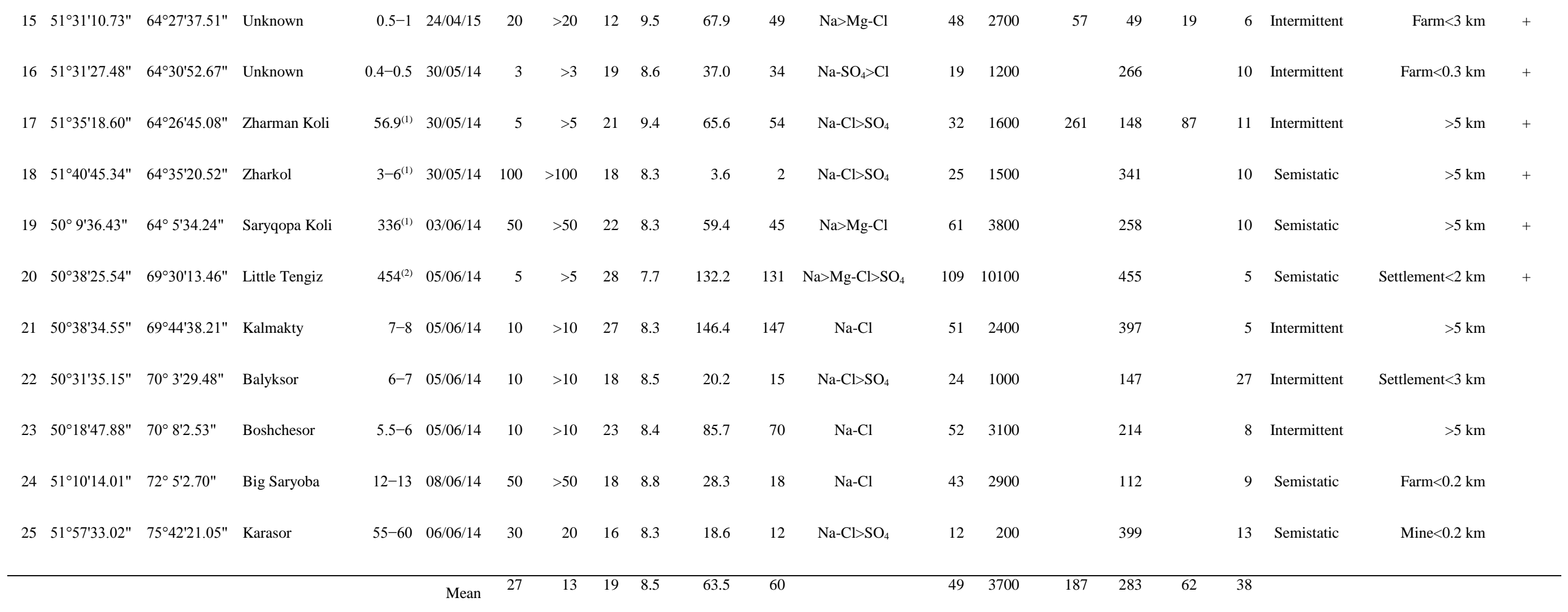

Legend

References: Area ${ }^{(1)}$ Bragina and Bragin, 2002.; Area ${ }^{(2)}$ Burlibaeva et al., 2007.

Disturbance: distance of human disturbance in kilometres based on Google Earth spatial measurement tool 
Table 2 Results of the Kruskal-Wallis ANOVA test (effects of human disturbances around the shallow saline lakes)

\begin{tabular}{clrrrrrc} 
Variables & Disturbance & N & Min & Median & Max & Chi-Square & p \\
\hline \multirow{2}{*}{ TOC } & $<5 \mathrm{~km}$ & 12 & 12 & 46 & 109 & \multirow{2}{*}{0.757} & 0.384 \\
& $>5 \mathrm{~km}$ & 13 & 25 & 48 & 125 & & \\
\hline \multirow{2}{*}{$\mathrm{TN}$} & $<5 \mathrm{~km}$ & 12 & 213 & 2776 & 10083 & 0.855 & 0.355 \\
& $>5 \mathrm{~km}$ & 13 & 1505 & 3108 & 9090 & & \\
\hline \multirow{2}{*}{$\mathrm{TP}$} & $<5 \mathrm{~km}$ & 12 & 49 & 247 & 1122 & \multirow{2}{*}{1.849} & 0.174 \\
& $>5 \mathrm{~km}$ & 13 & 26 & 187 & 397 & & \\
\hline \multirow{2}{*}{$\mathrm{CHL}$} & $<5 \mathrm{~km}$ & 12 & 5 & 20 & 378 & \multirow{2}{*}{2.663} & 0.103 \\
& $>5 \mathrm{~km}$ & 13 & 5 & 10 & 41 & & \\
\hline
\end{tabular}

Legend

Groups of human disturbance sources

$<5 \mathrm{~km}$ : Human disturbance exists within five $\mathrm{km}$

$>5 \mathrm{~km}$ : Human disturbance exists out of five $\mathrm{km}$

Types and distances of human disturbances sources are listed in Table 1 

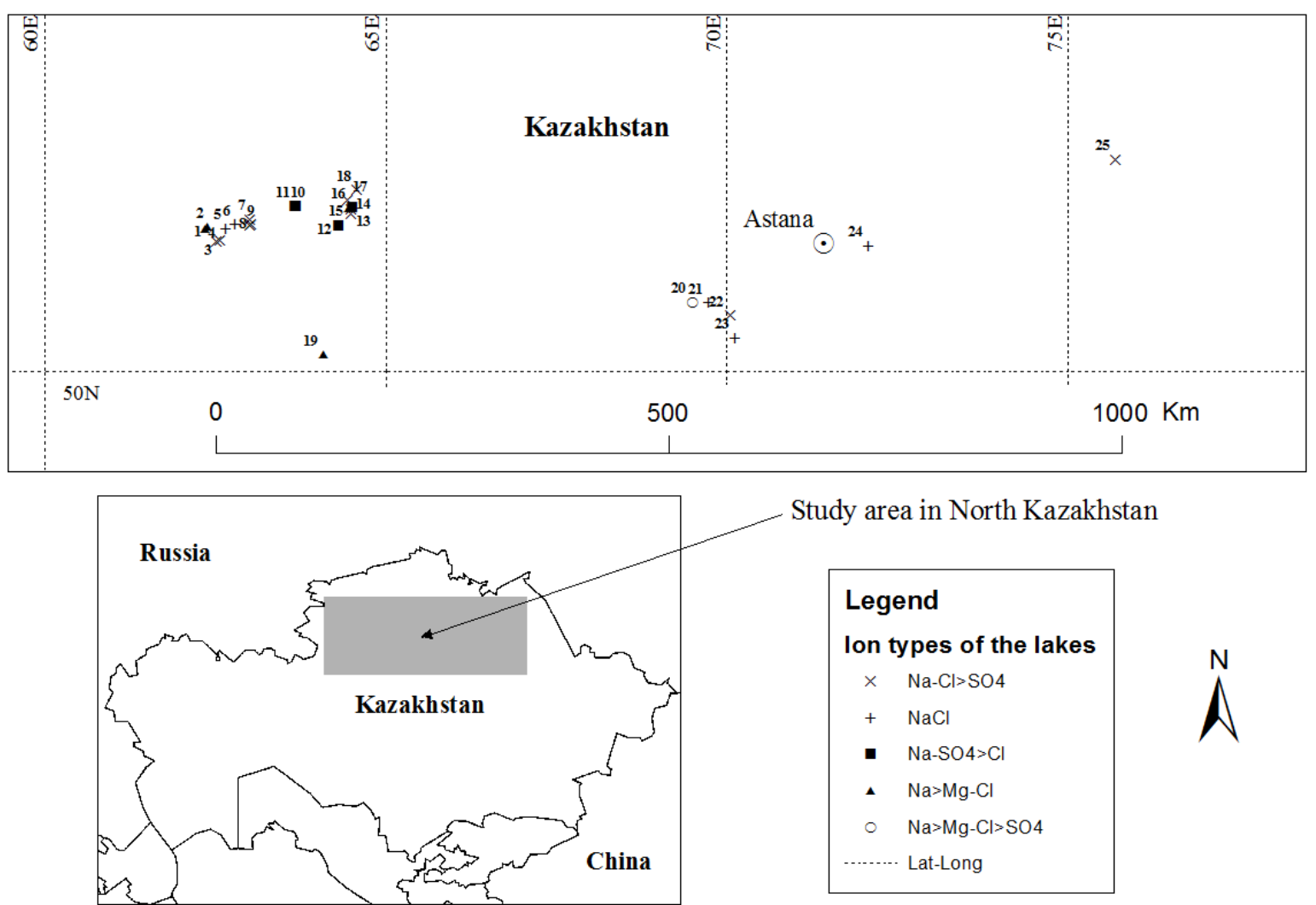

Fig 1 Geographical distribution and ion types of shallow saline steppe lakes investigated in North Kazakhstan
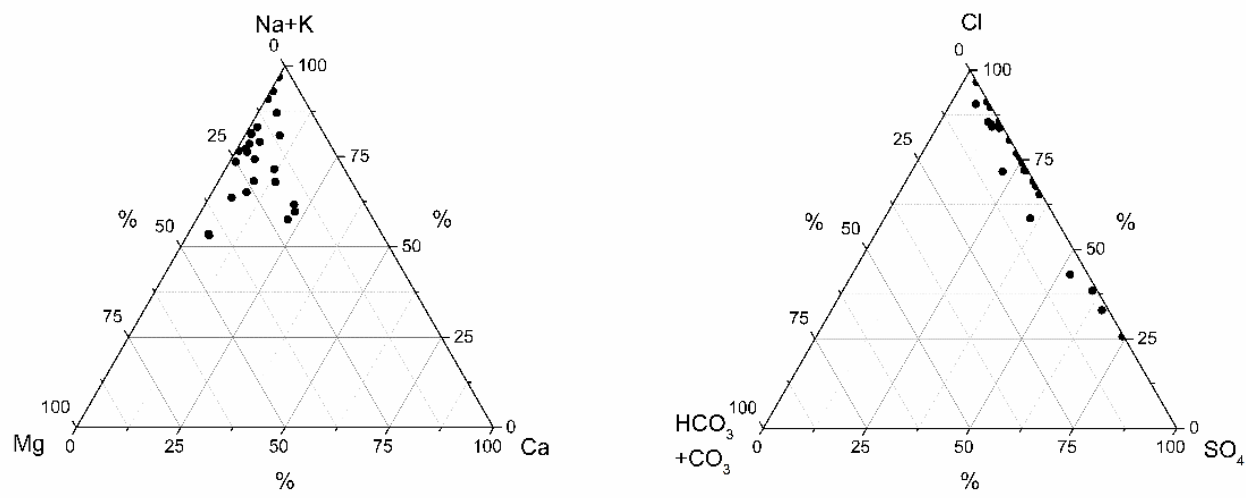

Fig 2 Ternary diagrams of ionic composition of investigated $(n=25)$ shallow saline lakes in North Kazakhstan Apices indicate an equivalent 100 percent of cations (a) and anions (b) 


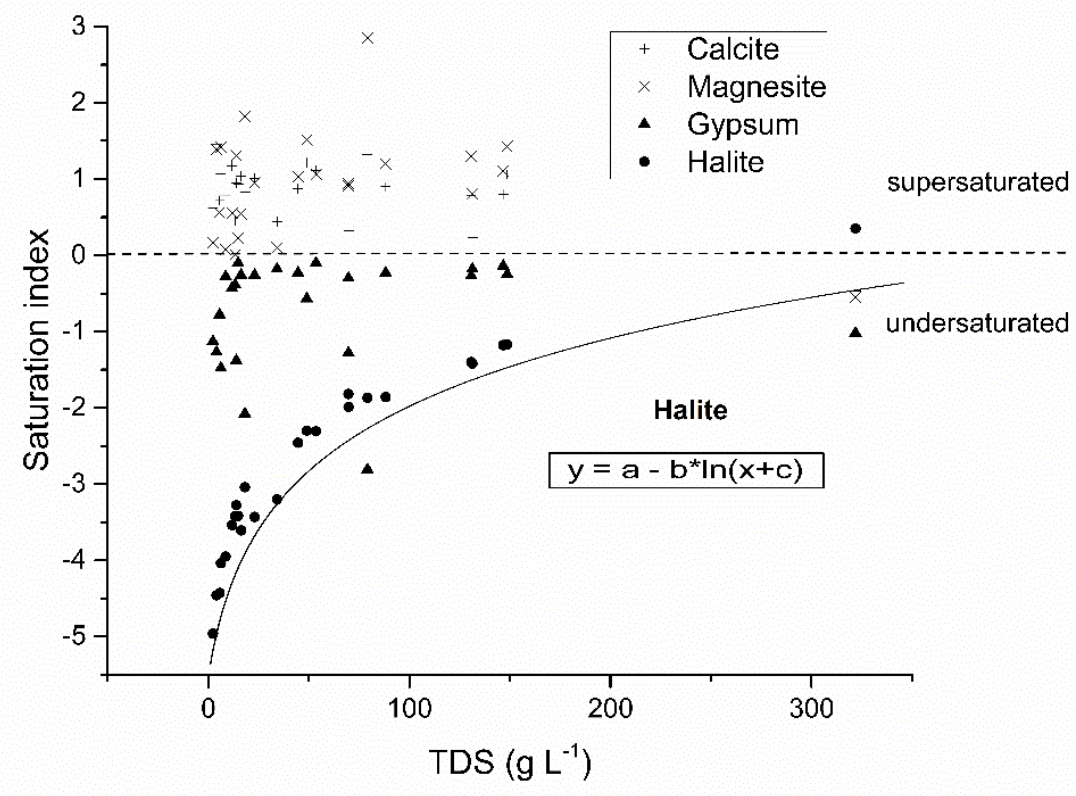

Fig 3 Relationships among TDS and saturation indexes of major minerals in shallow saline lakes in North Kazakhstan Parameters of the significant $(\mathrm{p}<0.05)$ fitting of Halite: $\mathrm{a}=-7.31 ; \mathrm{b}=-1.26 ; \mathrm{c}=5.95 ; \mathrm{n}=25 ; \mathrm{df}=22$; $r^{2}=0.967$ 


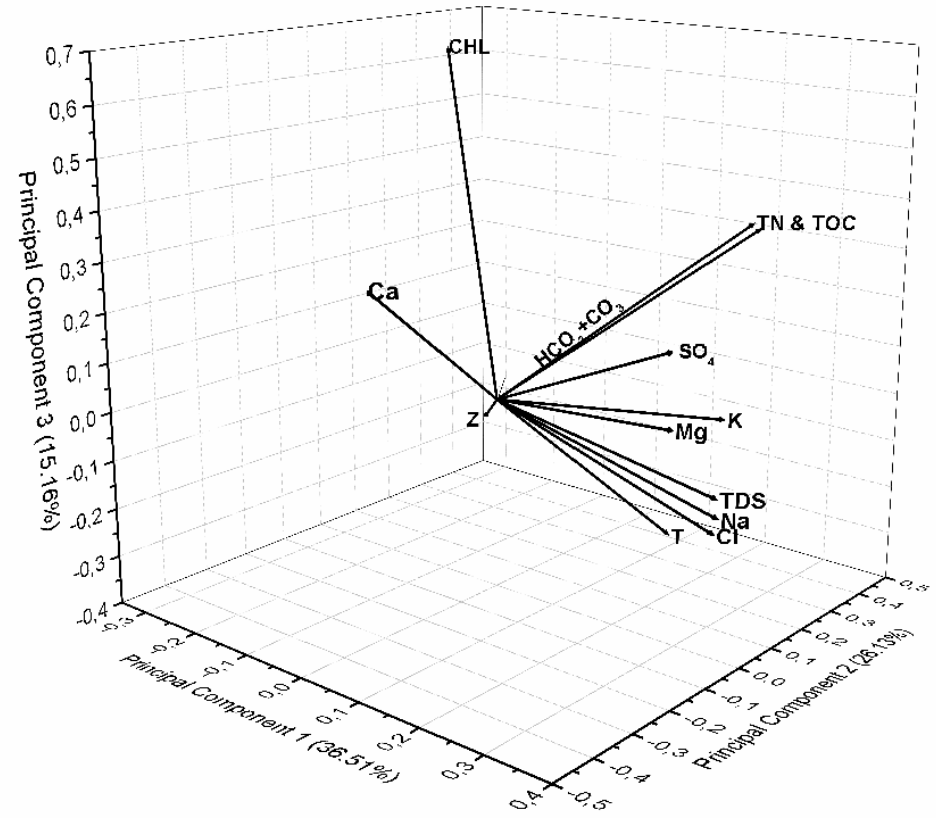

Fig 4 Principal component analysis (PCA) of the measured environmental parameters

The relation of variables with the three principal components:

PC 1: T, $\mathrm{Na}, \mathrm{K}, \mathrm{Mg}, \mathrm{Cl}, \mathrm{SO}_{4}$, TDS

PC 2: $\mathrm{Z}, \mathrm{HCO}_{3}+\mathrm{CO}_{3}, \mathrm{TOC}, \mathrm{TN}$

PC 3: $\mathrm{Ca}, \mathrm{CHL}$ 